\title{
Tissue- and stage-specific expression of a fatty acid binding protein- like gene from amphioxus Branchiostoma belcheri
}

\author{
Yongjun Wang ${ }^{1,2 \ddagger}$, Yuequn Zhang ${ }^{3 \ddagger}$, Shicui Zhang ${ }^{2 凶}$, Jianxiao Tian ${ }^{2}$ \\ and Shengjuan Jiang ${ }^{2}$ \\ ${ }^{1}$ Key Laboratory of Neuroregeneration, Nantong University, Nantong, PR China; ${ }^{2}$ Department of Marine Biol- \\ ogy, Ocean University of China, Qingdao, PR China; ${ }^{3}$ Department of Environment and Resources, Nantong \\ Agricultural College, Nantong, PR China
}

Received: 08 August, 2007; revised: 15 November, 2007; accepted: 05 December, 2007

available on-line: 18 January, 2008

\begin{abstract}
A cDNA clone encoding an amphioxus fatty acid binding protein-like (AmphiFABPL) protein was isolated from a gut cDNA library of Branchiostoma belcheri. It contained a $423 \mathrm{bp}$ open reading frame corresponding to a deduced protein of 140 amino acids with a predicted molecular mass of approximately $15.9 \mathrm{kDa}$. Phylogenetic analysis showed that AmphiFABPL fell outside the vertebrate clade of fatty acid binding proteins (FABPs), being positioned at the base of the chordate lineage, and was almost equally homologous to various vertebrate FABPs, suggesting that it may be the archetype of vertebrate FABPs. Both northern blotting and in situ hybridization analyses demonstrated that AmphiFABPL was expressed in the hepatic caecum and hind-gut, and although at a much lower level, it was also present in the endostyle, ovary and testis. In addition, whole-mount in situ hybridization revealed that AmphiFABPL was initially expressed in the posterior two thirds of the primitive gut, including the mid-gut where the hepatic caecum will form later, in 2-day larvae. The expression pattern is closely similar to that of the L-FABP and I-FABP genes in vertebrates, supporting the hypothesis that the hepatic caecum in the amphioxus is homologous to the vertebrate liver.
\end{abstract}

Keywords: FABP, amphioxus, chordate, evolution, expression, hybridization

\section{INTRODUCTION}

Fatty acid binding proteins (FABPs), encoded by a multigene family, are low molecular mass $(14-15 \mathrm{kDa})$ and highly conserved cytosolic proteins that bind non-covalently hydrophobic ligands such as fatty acids. The primary amino-acid sequences of FABP family members differ from each other, yet all FABPs have a similar tertiary structure consisting of two short $\alpha$-helices and 10 antiparallel $\beta$-strands (Zhang et al., 1997; Chmurzyńska, 2006). The $\beta$ strands are organized into two orthogonal $\beta$-sheets, giving the protein an overall clam shell-like shape (Bernlohr et al., 1997; Schaap et al., 2002). Many pu- tative physiological functions have been proposed for FABPs, including the promotion of cellular uptake and transport of fatty acids, targeting of fatty acids to specific metabolic pathways, and participation in the regulation of gene expression and cell growth (Haunerland \& Spener, 2004). To date, nine different types of FABPs have been documented in vertebrates, each being originally named according to their initial site of isolation, subsequently named based on sequence similarity to previously defined FABPs: liver FABP (L-FABP), intestinal FABP (IFABP), heart FABP (H-FABP), adipocyte FABP (AFABP), epidermal FABP (E-FABP), ileal FABP (IlFABP), brain FABP (B-FABP), myelin FABP (MP2)

\footnotetext{
\Corresponding author: Shicui Zhang, Department of Marine Biology, Ocean University of China, 5 Yushan Road, Qingdao 266003, PR China; tel.: 0086-532-8203-2787; fax: 0086-532-8203-2787; e-mail: sczhang@ouc.edu.cn 期ese authors contributed equally to the work.

Abbreviations: AP, alkaline phosphatase; BCIP, 5-bromo-4-chloro-3-indolylphosphate toluidine; DEPC, diethyl pyrocarbonate; Dig, Digoxigenin; EST, expressed sequence tag; NBT, nitroblue tetrazolium; PBS, phosphate-buffered saline; ORF, open reading frame; SDS, sodium dodecyl sulfate; SSC, saline sodium citrate buffer solution; UTR, untranslated region.
} 
and testis FABP (T-FABP) (Chmurzyńska, 2006). FABPs have also been isolated from invertebrates (Haunerland \& Chisholm, 1990), and nearly all invertebrate FABPs reported appear mainly related to the H-type proteins (Esteves \& Ehrlich, 2006).

Since the first identification of intestinal FABP by Ockner et al. (1972), vertebrate FABPs have been extensively studied. A large number of data show that FABP genes are expressed in a tissue-specific manner, yet most vertebrate tissues express several various FABP types. L-FABP, for example, is abundantly expressed in the liver, and recent studies have reported the expression of E-FABP, I-FABP and A-FABP in the liver as well (Owada et al., 2002; $\mathrm{Yu}$ et al., 2002). Moreover, L-FABP is also expressed at a lower level in the kidney, pancreas, intestine and lung (Gordon et al., 1985; Maatman et al., 1992; Schroeder et al., 1993). In contrast, I-FABP expression is mainly restricted to the digestive tract including intestine and stomach (Cohn et al., 1992; Veerkamp \& Maatman, 1995) although it is also expressed in other tissues such as ovary and testis (Sharma et al., 2004). H-FABP and E-FABP are both ubiquitously expressed: the former is most prominent in the cardiac and skeletal muscles, but also present in the kidney, lung, mammary tissue, placenta, testis, ovary, stomach and brain; the latter occurs widely in the skin, lung, heart and skeletal muscles, kidney, testis, adipose tissue, brain and retina (Zanotti, 1999). In addition to H-FABP and E-FABP, B-FABP and MP2 are also expressed in the nervous system including brain, retina and Schwann cells (Owada et al., 1996; Veerkamp \& Zimmerman, 2001). Finally, A-FABP is expressed in adipocytes and macrophages (Bernlohr et al., 1997; Fu et al., 2000). In most cases, the expression pattern of FABP genes appears similar in all vertebrates (Green et al., 1992; Shi \& Hayes, 1994; André et al., 2000; Pierce et al., 2000; Sharma et al., 2004).

Despite the extensive investigation of vertebrate FABPs, including gene expression studies at tissue and cellular level, over the past three decades (Agellon et al., 2002), little is known at present regarding the occurrence of FABPs in non-vertebrate chordates. Amphioxus, a basal chordate, has long been regarded as a model organism for insights into the origin and evolution of vertebrates (Holland et al., 2004). Information on its gene sequences and expression patterns has been widely used for interspecies comparative genome studies and developmental homology analysis (Wada \& Satoh, 1994; Holland \& Holland, 1999). In the course of expressed sequence tag (EST) generation from a gut cDNA library of amphioxus Branchiostoma belcheri, we isolated a gene exhibiting similarity to vertebrate FABP genes (GenBank accession number: DQ531633). The aims of this study were thus to characterize the amphioxus
FABP-like gene, and to examine its expression pattern in adults and developing embryos.

\section{MATERIALS AND METHODS}

Animals and embryos. Amphioxus B. belcheri were collected during the breeding season from the sandy bottom of the sea near Shazikou in the vicinity of Qingdao, transported to the laboratory and maintained at ambient photoperiod and temperature. The naturally fertilized eggs were pooled, and cultured at room temperature. The developing embryos and larvae at desired stages were fixed in fresh $4 \%$ paraformaldehyde in $100 \mathrm{mM}$ Mops in 100 $\mathrm{mM}$ phosphate buffer (pH 7.4) containing $500 \mathrm{mM}$ $\mathrm{NaCl}$ at $4^{\circ} \mathrm{C}$ overnight, and stored in $70 \%$ ethanol at $-20^{\circ} \mathrm{C}$ until used.

Cloning and sequence analysis of cDNA. The gut cDNA library of adult amphioxus was constructed with SMART cDNA Library Construction Kit (CLONTECH, Palo Alto, CA, USA) according to the method described previously (Liu et al., 2002). In large scale sequencing of the cDNA library with an ABI PRISM 377XL DNA sequencer, more than 5000 clones were analyzed for coding probability with the DNA Tools program (Rehm, 2001). Comparison against the GenBank protein database was performed using the BLAST network server at the National Center for Biotechnology Information (Altschul et al., 1997). Multiple protein sequences were aligned using the MegAlign program by the CLUSTAL W method in the DNASTAR software package (Burland, 2000). A phylogenetic tree was constructed by the neighbor-joining method within the PHYLIP 3.5c software package (Felsenstein, 1993) using 1000 bootstrap replicates.

Northern blotting. Total RNAs were prepared with Trizol (Gibco) from various tissues including the gill, muscle, testis, ovary, hepatic caecum, hind-gut and notochord of adult amphioxus. Northern blotting was performed according to a slightly modified method of Stelmanska et al. (2004) and Surmacz et al. (2006). A total of $4 \mu \mathrm{g}$ RNAs each was electrophoresed and blotted onto Nylon membrane (Osmonics Inc.). The blots were hybridized at high stringency with DIG-labeled AmphiFABPL riboprobe of about $600 \mathrm{bp}(1 \mu \mathrm{g} / \mathrm{ml}$ in DIG Easy $\mathrm{Hyb}$ ) for $15 \mathrm{~h}$ at $56^{\circ} \mathrm{C}$, and washed twice in $2 \times$ SSC with $0.1 \%$ SDS at $25^{\circ} \mathrm{C}$ for 5 min each and twice in $0.1 \times$ SSC with $0.1 \%$ SDS at $65^{\circ} \mathrm{C}$ for 20 min each. They were then incubated in a blocking solution ( $\mathrm{pH}$ 7.5) containing $100 \mathrm{mM}$ maleic acid, $150 \mathrm{mM} \mathrm{NaCl}$ and 1\% blocking reagent (Roche) and in the blocking solution with anti-DigoxigeninAP (Roche) diluted 1:10 000 for 1 and $2 \mathrm{~h}$, respectively, at room temp. After washing with $100 \mathrm{mM}$ 
maleic acid buffer (pH 7.5) with $150 \mathrm{mM} \mathrm{NaCl}$ and $0.3 \%$ Tween 20 and $100 \mathrm{mM}$ Tris/ $\mathrm{HCl}$ buffer $(\mathrm{pH}$ 9.5) with $100 \mathrm{mM} \mathrm{NaCl}$, the hybridized bands were visualized by BM-Purple (Roche).

In situ hybridization histochemistry. Sexually mature amphioxus were cut into 5 or 6 pieces and fixed in freshly prepared $4 \%$ paraformaldehyde in $100 \mathrm{mM}$ phosphate buffer $(\mathrm{pH} 7.4)$ at $4^{\circ} \mathrm{C}$ for $8 \mathrm{~h}$. The samples were dehydrated, embedded in paraffin, and sectioned at $7 \mu \mathrm{m}$. The sections were mounted onto poly-L-lysine coated slides, dried at $42^{\circ} \mathrm{C}$ for $36 \mathrm{~h}$, and de-waxed in xylene for $20 \mathrm{~min}$ (two changes for $10 \mathrm{~min}$ each), followed by immersion in absolute ethanol for $10 \mathrm{~min}$ (two changes for $5 \mathrm{~min}$ each). They were then re-hydrated, and brought to double distilled water treated with $0.1 \%$ DEPC. After digestion with $5 \mu \mathrm{g} / \mathrm{ml}$ proteinase $\mathrm{K}$ (Merck) in $100 \mathrm{mM}$ Tris/ $\mathrm{HCl}$ buffer $(\mathrm{pH}$ 8.0) with $50 \mathrm{mM}$ EDTA at $37^{\circ} \mathrm{C}$ for $30 \mathrm{~min}$, the sections were post-fixed in $4 \%$ paraformaldehyde in $10 \mathrm{mM}$ phosphate buffer ( $\mathrm{pH} 7.4$ ) at room temp. for $20 \mathrm{~min}$, and then acetylated in freshly prepared $100 \mathrm{mM}$ triethanolamine $/ \mathrm{HCl}(\mathrm{pH} 8.0$ ) with $0.25 \%$ acetic anhydrite at room temp. for $10 \mathrm{~min}$, de-hydrated with graded ethanol, pre-hybridized in a hybridization buffer containing 50\% deionized formamide (v/v), $100 \mu \mathrm{g} /$ $\mathrm{ml}$ heparin, $5 \times \mathrm{SSC}, 0.1 \%$ Tween $20,5 \mathrm{mM}$ EDTA, $1 \times$ Denhardt's solution and $0.2 \mathrm{mg} / \mathrm{ml}$ salmon sperm DNA at $55^{\circ} \mathrm{C}$ for $3 \mathrm{~h}$, and hybridized in the same hybridization buffer with $1 \mu \mathrm{g} / \mathrm{ml}$ AmphiFABPL riboprobe at $55^{\circ} \mathrm{C}$ for $16 \mathrm{~h}$ in a moist chamber. Subsequently, the sections were subjected to RNase A (Promega) digestion $(20 \mu \mathrm{g} / \mathrm{ml}$ in $2 \times \mathrm{SSC})$ at $37^{\circ} \mathrm{C}$ for $30 \mathrm{~min}$, washed three times in $100 \mathrm{mM}$ Tris/HCl ( $\mathrm{pH}$ 7.4) with $150 \mathrm{mM} \mathrm{NaCl}$ (15 min each), pre-incubated in $1 \%$ blocking reagent (Roche) in $100 \mathrm{mM}$ Tris/ $\mathrm{HCl}$ ( $\mathrm{pH} 7.4$ ) with $150 \mathrm{mM} \mathrm{NaCl}$ at room temp. for $1 \mathrm{~h}$, and incubated with anti-Dig AP-conjugated antibody diluted $1: 2000$ in $1 \%$ blocking reagent in $100 \mathrm{mM}$ Tris/ $\mathrm{HCl}$ with $150 \mathrm{mM} \mathrm{NaCl}(\mathrm{pH} \mathrm{7.4)}$ at room temp. for $2 \mathrm{~h}$. After washing three times in $100 \mathrm{mM}$ Tris/ $\mathrm{HCl}$ (pH 8.0) containing $100 \mathrm{mM} \mathrm{NaCl}$ and $50 \mathrm{mM} \mathrm{MgCl}$ (5 min each), the sections were incubated with a coloring solution consisting of 4.5 $\mu \mathrm{g} / \mathrm{ml} \mathrm{NBT}$ and $3.5 \mu \mathrm{g} / \mathrm{ml} \mathrm{BCIP}$ in $100 \mathrm{mM}$ Tris $/ \mathrm{HCl}$ (pH 8.0) with $100 \mathrm{mM} \mathrm{NaCl}$ and $50 \mathrm{mM} \mathrm{MgCl}_{2}$ (Boehringer Mannheim) in dark for 3-12 $\mathrm{h}$. The coloring reaction was stopped in $100 \mathrm{mM}$ Tris/ $\mathrm{HCl}(\mathrm{pH}$ 8.0) with $1 \mathrm{mM}$ EDTA for $10 \mathrm{~min}$, and the sections were then rinsed in distilled water, dehydrated, mounted in Canada balsam, and photographed under a BX51 Olympus microscope.

Whole-mount in situ hybridization. Wholemount in situ hybridization was carried out by the method of Holland et al. (1996). Briefly, embryos and larvae stored in $70 \%$ ethanol were re-hydrated. After several washes in PBS (0.1 M phosphate buffer
$\mathrm{pH} 7.4,0.9 \% \mathrm{NaCl})$, specimens were digested with $10 \mu \mathrm{g} / \mathrm{ml}$ proteinase K in PBS for $10 \mathrm{~min}$. Digestion was stopped with $2 \mathrm{mg} / \mathrm{ml}$ glycine in PBS (10 min) and specimens were refixed for $1 \mathrm{~h}$ in $4 \%$ paraformaldehyde in PBS. After washing in PBS, specimens were acetylated with $0.25 \%$ acetic anhydride in 0.1 $\mathrm{M}$ triethanolamine, washed in PBS followed by prehybridization in a hybridization buffer $(50 \%$ deionized formamide $(\mathrm{v} / \mathrm{v}), 100 \mu \mathrm{g} / \mathrm{ml}$ heparin, $5 \times \mathrm{SSC}$, $0.1 \%$ Tween 20, 5 mM EDTA, $1 \times$ Denhardt's solution) at $60^{\circ} \mathrm{C}$ for $3 \mathrm{~h}$. Hybridization was performed in the same hybridization buffer with $1 \mu \mathrm{g} / \mathrm{ml} \mathrm{Am-}$ phiFABPL antisense riboprobe at $60^{\circ} \mathrm{C}$ for $16 \mathrm{~h}$. Then the embryos and larvae were subjected to RNase A digestion $(20 \mu \mathrm{g} / \mathrm{ml}$ in $2 \times \mathrm{SSC})$ at $37^{\circ} \mathrm{C}$ for $20 \mathrm{~min}$, washed in $2 \times$ SSC, $0.1 \%$ Tween $20(2 \times 20 \mathrm{~min})$ followed by $0.2 \times$ SSC, $0.1 \%$ Tween $20(1 \times 20 \mathrm{~min})$, pre-incubated in $1 \%$ blocking reagent (Roche) in 100 $\mathrm{mM}$ Tris/ $\mathrm{HCl}(\mathrm{pH} 7.4)$ with $150 \mathrm{mM} \mathrm{NaCl}$ at room temp. for $2 \mathrm{~h}$, and incubated with anti-Dig AP-conjugated antibody diluted $1: 2000$ in 1\% blocking reagent in $100 \mathrm{mM}$ Tris/ $\mathrm{HCl}$ with $150 \mathrm{mM} \mathrm{NaCl}(\mathrm{pH}$ 7.4) at $4^{\circ} \mathrm{C}$ overnight. After washing three times in PBS Tween 20, the specimens were transferred to alkaline phosphatase buffer $(100 \mathrm{mM} \mathrm{NaCl}, 50 \mathrm{mM}$ $\mathrm{MgCl}_{2}, 100 \mathrm{mM}$ Tris/HCl, pH 9.6, 0.1\% Tween 20), incubated with a coloring solution consisting of 4.5 $\mu \mathrm{g} / \mathrm{ml} \mathrm{NBT}$ and $3.5 \mu \mathrm{g} / \mathrm{ml} \mathrm{BCIP}$ in $100 \mathrm{mM}$ Tris/HCl ( $\mathrm{pH}$ 8.0) with $100 \mathrm{mM} \mathrm{NaCl}$ and $50 \mathrm{mM} \mathrm{MgCl}_{2}$ in dark. Levamisole was used as an inhibitor of endogenous alkaline phosphatases. Reactions were stopped in phosphate buffer after 1 to $12 \mathrm{~h}$. Embryos and larvae were cleared in $80 \%$ glycerol in phosphate buffer and viewed and photographed using an Olympus microscope. Control experiment was performed in parallel using sense probes.

\section{RESULTS AND DISCUSSION}

\section{Sequence, structure and phylogeny of amphioxus FABP-like cDNA}

The cDNA (GenBank accession number: DQ531633) obtained from the gut cDNA library of amphioxus B. belcheri is $631 \mathrm{bp}$ long, and its longest open reading frame codes for a protein of 140 amino acids with a predicted molecular mass of approx. $15.9 \mathrm{kDa}$. The $5^{\prime}$ untranslated region (UTR) is 96 bp long with three in-frame stop codons, and the 3' UTR is $112 \mathrm{bp}$ long with a polyadenylation signal AATAAA and a polyadenylyl tail (Fig. 1). An initial BLASTp search at NCBI showed that the protein encoded by the cDNA has a lipocalin domain (residues 7-97) characteristic of FABPs, and the highest hits were Fasciola hepatica FABP (score: 53.9, E value: 
GGTGCAACGTCGGTGTTTTCACACACCTGAGCGAACCTCCGCCAGACCAGACCGTCCTCG 60 CCCACCTGAGAAGCCTAAACACCGCAACAAGTCAAGATGCCTTTTCCTGTGGACAAATTT 120 $\begin{array}{lllllllll}M & \text { P } & \text { F } & \text { V D } & \text { K } & \text { F } & 8\end{array}$ TGCGGAACGTGGAAGCACGGCTCCCATTCCGACAACTACCTTCAGATGATGGAGAAATTT 180

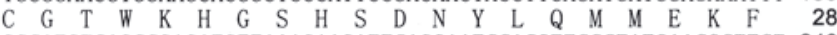
GGCATGTCAGCCGAGATGTTAAAGAAGATTCAGGAATCCACGTTCCCTATGAACGCTTCT 240 G M S A E M L K CTGGTAGGAGACAAGTTAACATTTAAGGTGGAGTTCGAGGGGAAGACCTATGAGAACAAC 300

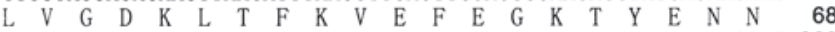
TTCACCTTGGGCGTGGAGGGGGAGGAGGAAGATGCAACCTCTGGCAAGAAGCGAAAGGTG 360 $\begin{array}{lllllllllllllllllllll}F & T & L & G & V & E & G & E & E & E & D & A & T & S & G & K & K & R & K & V & 88\end{array}$ ACCTACACCATAGAGGGAGACCACCTGGTGTCGGTGTACCCAGATCCTGACGGGAAGGTT 420 $\begin{array}{llllllllllllllllllllll}T & \mathrm{Y} & \mathrm{T} & \mathrm{I} & \mathrm{E} & \mathrm{G} & \mathrm{D} & \mathrm{H} & \mathrm{L} & \mathrm{V} & \mathrm{S} & \mathrm{V} & \mathrm{Y} & \mathrm{P} & \mathrm{D} & \mathrm{P} & \mathrm{D} & \mathrm{G} & \mathrm{K} & \mathrm{V} & 108\end{array}$ ACCAGTCGCGTCTGCCGCCATTTTGATGATGACGACACCATCCATACTGATATCAAAGCT 480 $\begin{array}{lllllllllllllllllllll}T & S & R & V & C & R & H & F & D & D & D & D & T & I & H & T & D & I & K & A & 128\end{array}$ GGAGACGTGGAGGCCTGGACAAAATCCAAGCGCTGCTAGACGTCCGAGAGAACGTTGACC 540 G D V E A W T K S K R C * CCAGTGGACCAGACTTGGCTTAGATGTTTGTAGTGGTTTGCTCTG AATAAAGCATCTGAA 600 CAAAAAAAAAAAAAAAAAAAAAAAAAAAAAA
Figure 1. Nucleotide and deduced amino-acid sequences of AmphiFABPL.

GenBank accession number of the cDNA is DQ531633. The asterisk represents the stop codon. The polyadenylation signal is shaded black with white lettering, and three in-frame stop codons within the 5' UTR are underlined. The numbering of the nucleotide and aminoacid sequences is shown to the right. 2e-06), Danio rerio I-FABP (score: 49.3, E value: 5e05 ) and D. rerio B-FABP (score: 49.3 , E value: 5e-05). In addition, prediction by the PredictPrediction program (http://swissmodel.expasy.org/) revealed the presence of two $\alpha$-helices and eleven $\beta$-strands in the protein encoded by the cDNA (Fig. 2). Compared with other FABPs, the last $\beta$-strand in the protein has split into two. These indicate that the cDNA encodes an amphioxus FABP-like protein, and is thus designated AmphiFABPL.

To shed light on the evolutionary position of AmphiFABPL, a phylogenetic tree was constructed
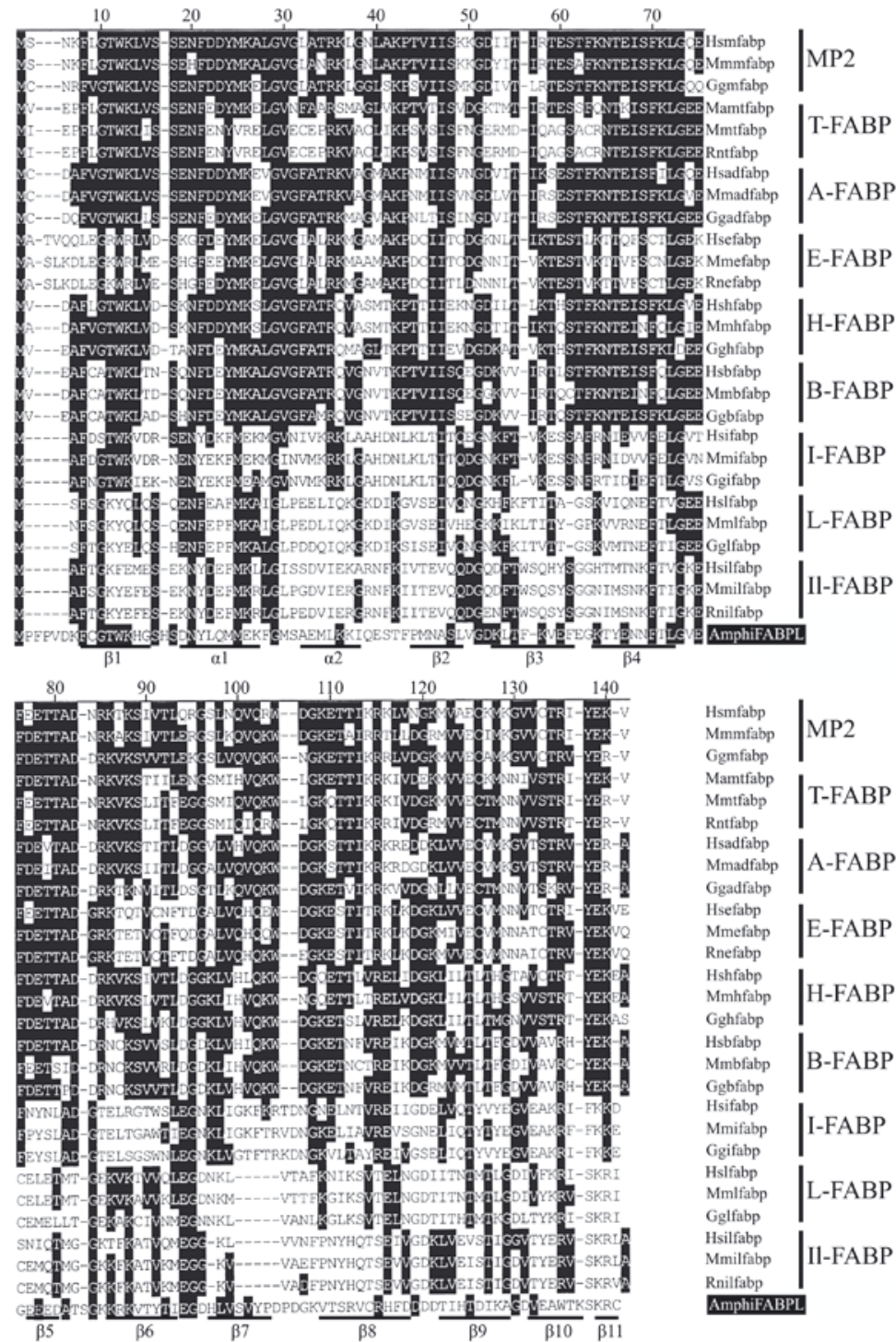

Figure 2. Alignment of various FABP sequences including AmphiFABPL.

Shaded (with solid black) are amino-acid residues that match the consensus. Gaps introduced into sequences to optimize alignment are represented by (-). The positions of two alpha helices designed $\alpha 1$ and $\alpha 2$, and of $11 \beta$-strands, designed $\beta 1-\beta 11$ of the holo form of AmphiFABPL (PredictPrediction program) are indicated under the AmphiFABPL sequence. Sequences obtained from Genbank or Swissprot are: Human Homo sapiens MP2 (Hsmfabp; BAA03726), A-FABP (Hsadfabp; AAH03672), H-FABP (Hshfabp; P05413), B-FABP (Hsbfabp; AAB87141), E-FABP (Hsefabp; Q01469), Il-FABP (Hsilfabp; AAB82751), L-FABP (Hslfabp; AAA52418), I-FABP (Hsifabp; AAA52417); Mouse Mus musculus T-FABP (Mmtfabp; NP_035728), MP2 (Mmmfabp; AAH99520), A-FABP (Mmadfabp; NP 077717), H-FABP (Mmhfabp; NP_034304), B-FABP (Mmbfabp; NP_067247), E-FABP (Mmefabp; Q05816), Il-FABP (Mmilfabp; NP_032401), L-FABP (Mmlfabp; NP 059095), I-FABP (Mmifabp; NP_032006); Chicken Gallus gallus MP2 (Ggmfabp; XP_ 418309), A-FABP (Ggadfabp; NP_989621), H-FABP (Gghfabp; Q6DRR5), B-FABP (Ggbfabp; NP_990639), L-FABP (Gglfabp; NP 989523), I-FABP (Ggifabp; NP_001007924); Rat Rattus norvegicus T-FABP (Rntfabp; NP_074045), E-FABP (Rnefabp; NP_665885), Il-FABP (Rnilfabp; NP_058794); Rhesus monkey Macaca mulatta T-FABP (Mamtfabp; XP_001092133). 


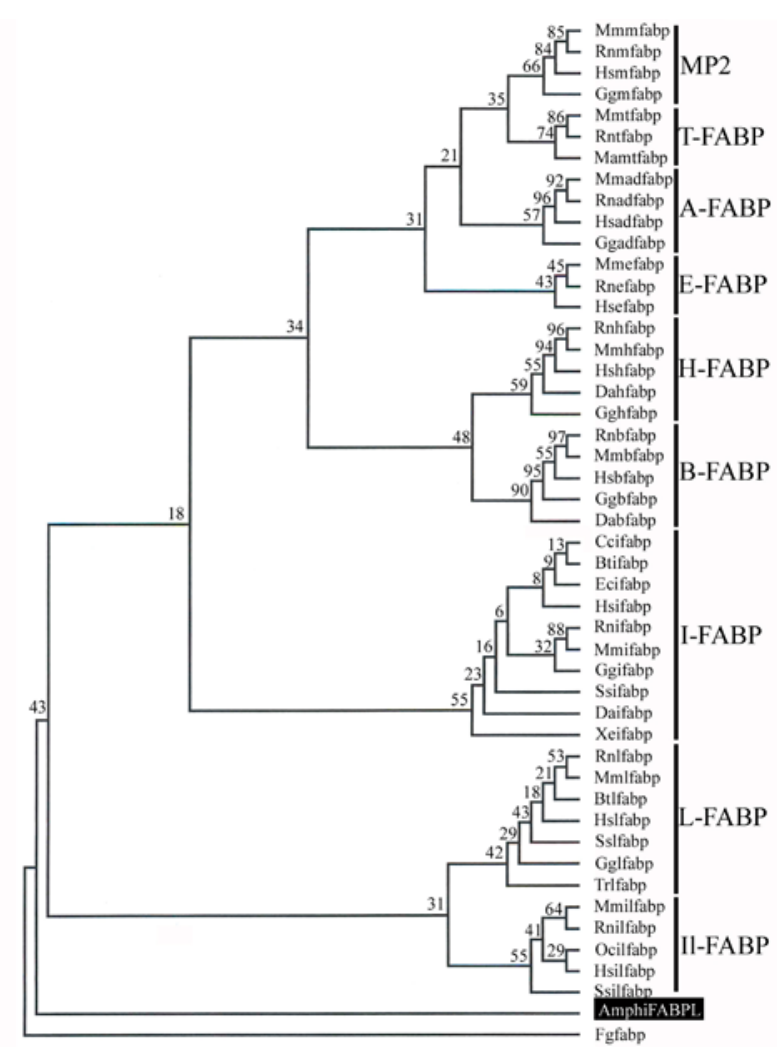

Figure 3. FABP phylogenetic tree.

The tree was constructed using the sequence of AmphiFABPL (shaded black with white lettering) and those of other FABPs from 13 representative vertebrates by the neighbor-joining method within the package PHYLIP 3.5c. Bootstrap majority consensus values on 1000 replicates are indicated at each branch point in percent. The Fasciola gigantica fatty acid binding protein was used as the outgroup. Sequences obtained from GenBank and Swissprot are: Rat Rattus norvegicus A-FABP (Rnadfabp; NP_445817), H-FABP (Rnhfabp; AAF19003), B-FABP (Rnbfabp; P55051), L-FABP (Rnlfabp; AAA41140), I-FABP (Rnifabp; P02693); Dog Canis familiaris I-FABP (Cfifabp; XP_545047); Rabbit Oryctolagus cuniculus Il-FABP (Ocilfabp; P50119); Pig Sus scrofa L-FABP (Sslfabp; ABA19231), I-FABP (Ssifabp; NP_001026950), Il-FABP (Ssilfabp; P10289); Zebrafish Danio rerio H-FABP (Dahfabp; Q8UVG7), B-FABP (Dabfabp; Q9I8N9), I-FABP (Daifabp; Q9PRH9); Bovine Bos taurus L-FABP (Btlfabp; NP_787011), I-FABP (Btifabp; NP 001020503); Takifugu rubripes L-FABP (Trlfabp; AAC60290); Horse Equus caballus I-FABP (Ecifabp; AAT08144); Frog Xenopus I-FABP (Xeifabp; Q91775); Fasciola gigantica (Fgfabp; AAB06722). For other abbreviations, see Fig. 2.

using the amino-acid sequences of 48 representative FABPs including all 9 different types of FABPs and AmphiFABPL from 13 vertebrate species and one amphioxus species using the Fasciola gigantica FABP as the outgroup. It was found that AmphiFABPL fell outside the vertebrate clade of FABPs, and was positioned at the base of the chordate lineage (Fig. 3), suggesting that AmphiFABPL may be the archetype of FABPs. This seems further corroborated by the comparison of amino-acid sequences, which revealed

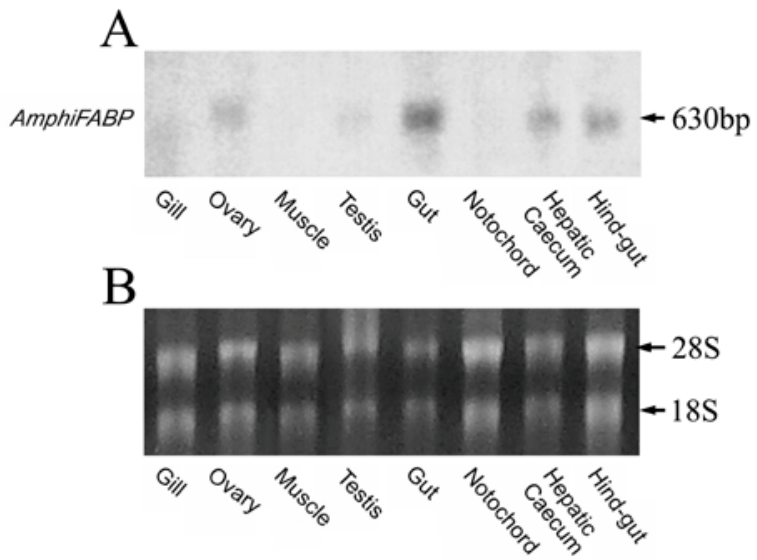

Figure 4. Northern blotting analysis of AmphiFABPL transcripts in different tissues of amphioxus.

A total of $4 \mu \mathrm{g}$ RNA for each sample was analyzed in $1.2 \%$ agarose formaldehyde denaturing gel. (A) The blot hybridized with DIG-labeled amphioxus AmphiFABPL RNA probe. The arrow indicates the position of molecular size equivalent to $630 \mathrm{bp}$. (B) Gel stained with ethidium bromide to control for the amount of RNA loaded.

that AmphiFABPL shares 21.2-22.7\%, 17.4-18.9\%, $21.2-25 \%, 15.6-17.0 \%, 20.3-23.3 \%, 18.9-20.5 \%, 20.5 \%$, $19.7-20.5 \%$ and $17.2-18 \%$ identity with MP2, TFABP, A-FABP, E-FABP, H-FABP, B-FABP, I-FABP, L-FABP and Il-FABP (Fig. 2), respectively, indicating that the sequence of AmphiFABPL is almost equally similar to those of various FABPs in vertebrates.

\section{Tissue- and stage-specific expression of AmphiFABPL gene}

Northern blotting was conducted to assess the size of the AmphiFABPL transcript and its tissue distribution. As shown in Fig. 4, a single 630 bp band of AmphiFABPL transcript was detected in the hepatic caecum and hind-gut, and although at much lower levels, it was also present in the ovary and testis. In contrast, no hybridization signal was observed in the gill, muscle, neural tube and notochord. In situ hybridization also revealed a similar tissue distribution pattern of AmphiFABPL transcript in the hepatic caecum, hind-gut, endostyle, ovary and testis (Fig. 5). The hepatic caecum in amphioxus has been long considered to be the precursor of vertebrate liver (Müller, 1844; Welsch, 1975; Ruppert, 1997; Liang et al., 2006a; 2006b). It is of interest to note that the abundant expression of AmphiFABPL in the hepatic caecum suggests it belongs to the liver type, while its predominant expression in the hind-gut implies it is similar to the intestinal type. It appears that AmphiFABPL exhibits similarity to both L-FABP and I-FABP, possibly representing a type of FABP with combined features of both L-FABP and I-FABP in vertebrates. Evolutionary tree data have suggested 

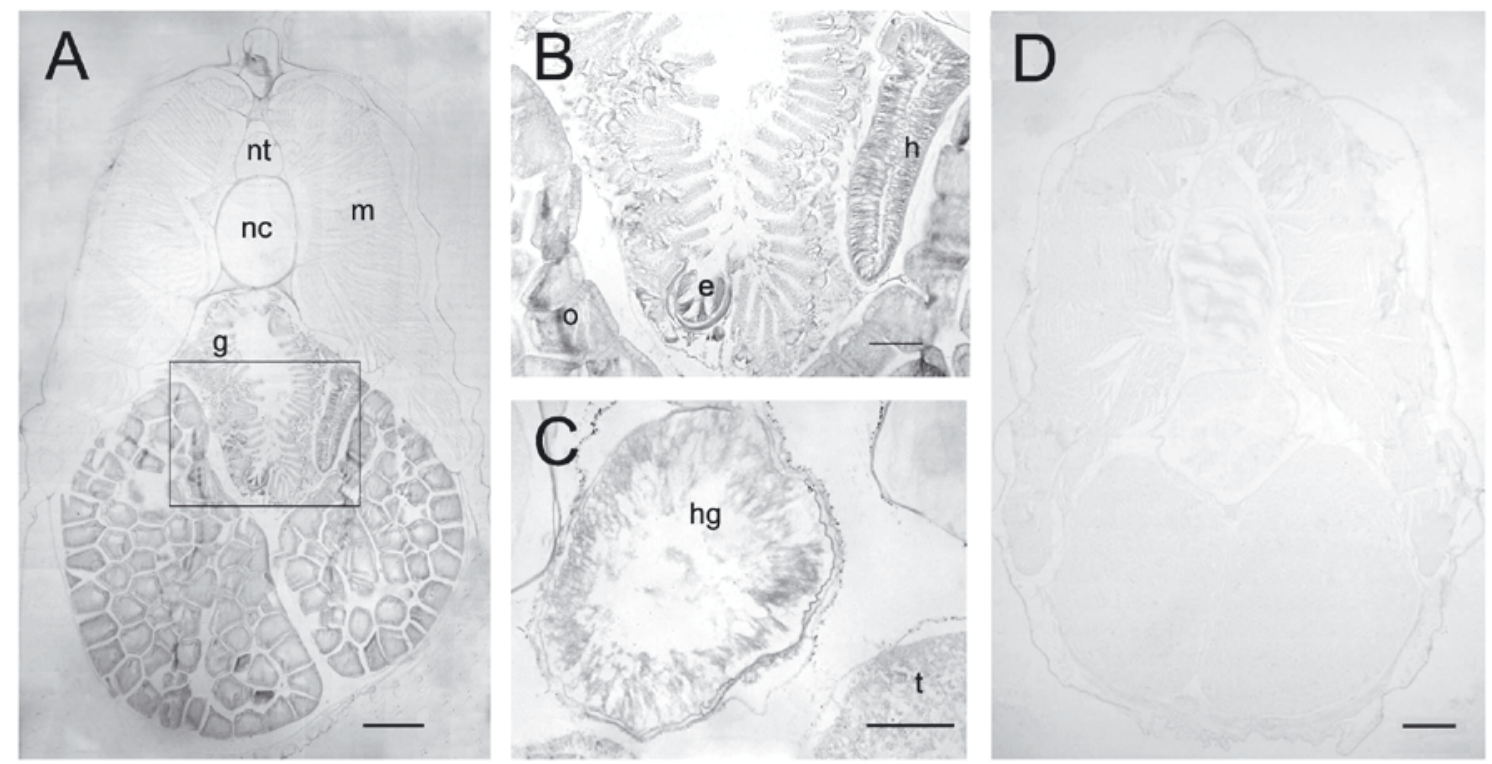

Figure 5. In situ hybridization of AmphiFABPL in different tissues of amphioxus.

(A) A transverse section of amphioxus. (B): Expanded boxed region of (A) showing positive signals in the hepatic caecum, ovary and endostyle. (C) A section showing the presence of AmphiFABPL mRNA in the hind-gut and testis. (D) Control processed and hybridized similarly in the presence of sense, instead of anti-sense probe. No signal was seen in the control. nt, neural tube; nc, notochord; e, endostyle; g, gill; m, muscle; o, ovary; h, hepatic caecum; hg, hind-gut; $t$, testis. Scale bars: $300 \mu \mathrm{m}$ in (A) and (D), $100 \mu \mathrm{m}$ in (B) and (C).
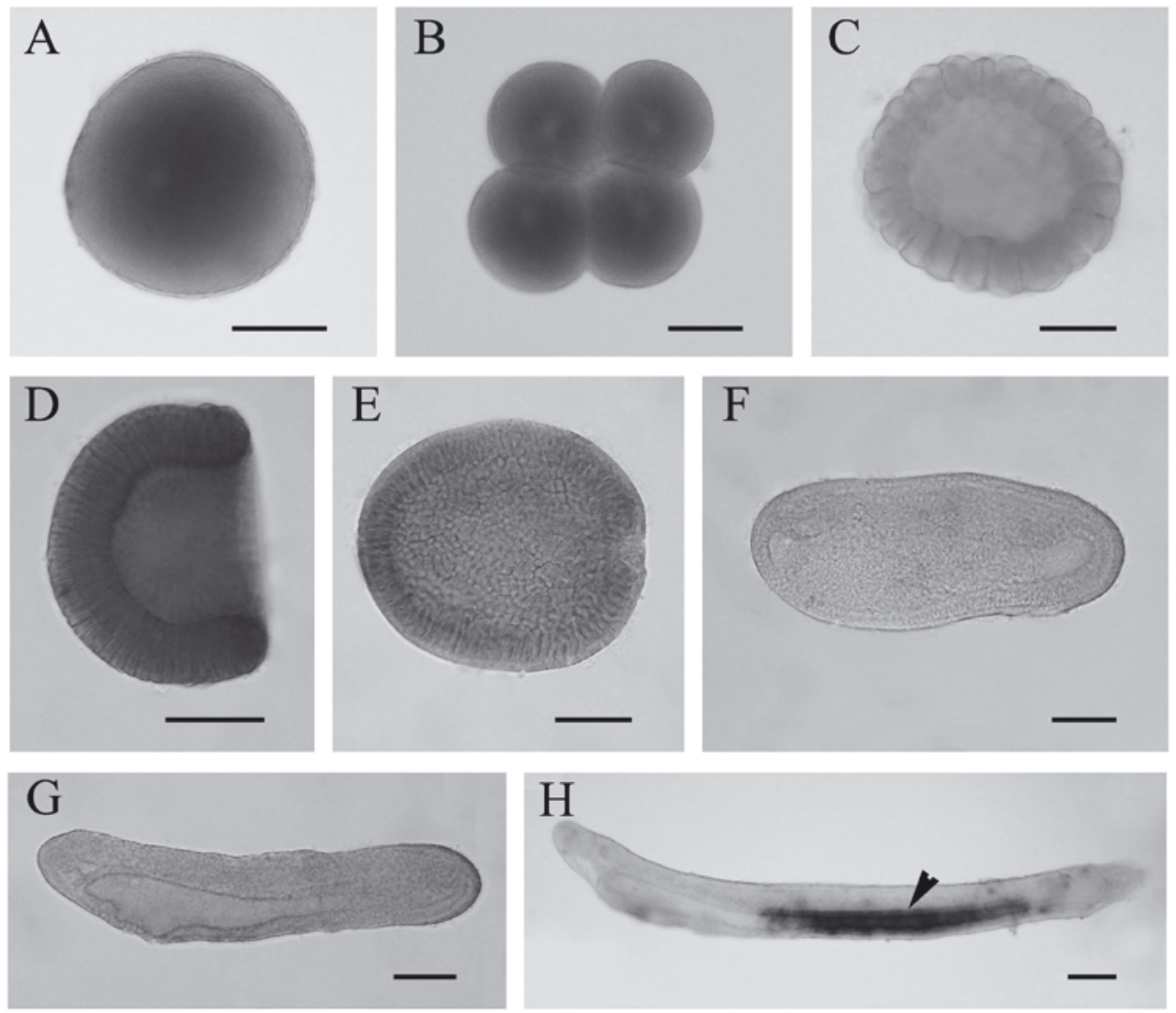

Figure 6. Expression of AmphiFABPL in amphioxus embryos and larvae by whole mount in situ hybridization. Anterior is to the left and dorsal is up in all whole mounts except for blastula. (A) A 1-cell embryo; (B) A 4-cell blastula; (C) A blastula of $4 \mathrm{~h}$; (D) A gastrula of $6 \mathrm{~h}$; (E) A neurula of $12 \mathrm{~h}$; (F) A neurula of $16 \mathrm{~h}$; (G) A 1-day larva showing no positive signal; and (H) A 2-day larva showing the presence of AmphiFABPL transcripts in the primitive gut (arrowhead). Scale bar $=50 \mu \mathrm{m}$. 
that gene duplication leading to the divergence of three branches of FABPs, which $\mathrm{H}-$-, L-, and I-FABPs belong to, must have occurred before the vertebrate/ invertebrate split (Chan et al., 1985; Cavagnari et al., 2000), however, only H-FABPs have been reported so far for nearly all invertebrates (Esteves \& Ehrlich, 2006). The identification of AmphiFABPL and its expression pattern in adult amphioxus apparently provide evidence supporting the gene duplication hypothesis.

Expression of AmphiFABPL during embryogenesis was examined by whole-mount in situ hybridization. An AmphiFABPL transcript was not detectable until the stage of 1-day larva. A strong positive signal was initially detected in the posterior two thirds of the primitive gut, including the midgut where the hepatic caecum will form later in development (Conklin, 1932), in 2-day larvae (Fig. 6). The spatial and temporal expression pattern of $A m-$ phiFABPL is most closely similar to that of I-FABP in zebrafish (André et al., 2000). It is known that fatty acids are mainly absorbed in the proximal half of the intestine in vertebrates. Whether the occurrence of AmphiFABPL in the primitive gut suggests the gain of a fatty acid absorbance role merits a detailed study.

The liver is an endoderm-derived organ that evolved in vertebrates. It has been shown that LFABP is primarily expressed in the liver, and IFABP is expressed in the liver as well in addition to its expression in the intestine (Yu et al., 2000; Owada et al., 2002). Similarly, AmphiFABPL is expressed predominantly in the hepatic caecum and hind gut and exclusively in the developing primitive gut including the region where the hepatic caecum will develop. This apparently agrees with the hypothesis that the vertebrate liver evolved from the hepatic caecum of an amphioxus-like ancestor initially proposed by Müller (1844).

\section{Acknowledgements}

This work was financially supported by the Jiangsu Province Education Commission Natural Science Foundation, People's Republic of China (Grant Number: 06KJB180086); Ministry of Education of China (200404023014) and the National Science Foundation of China (Grant Number: 30470203; 30670283).

\section{REFERENCES}

Agellon LB, Toth MJ, Thomson AB (2002) Intracellular lipid binding proteins of the small intestine. Mol Cell Biochem 239: 79-82.

Altschul SF, Madden TL, Schaffer AA, Zhang J, Zhang Z, Miller W, Lipman DJ (1997) Gapped BLAST and PSI-
BLAST: a new generation of protein database search programs. Nucleic Acids Res 25: 3389-3402.

André M, Ando S, Ballagny C, Durliat M, Poupard G, Briancon C, Babin PJ (2000) Intestinal fatty acid binding protein gene expression reveals the cephalocaudal patterning during zebrafish gut morphogenesis. Int $J$ Dev Biol 44: 249-252.

Bernlohr DA, Coe NR, Simpson MA, Hertzel AV (1997) Regulation of gene expression in adipose cells by polyunsaturated fatty acids. Adv Exp Med Biol 422: 145-156.

Burland TG (2000) DNASTAR's Lasergene sequence analysis software. Methods Mol Biol 132: 71-91.

Cavagnari BM, Tatian M, Sahade RJ, Esnal GB, Santome JA (2000) A fatty acid-binding protein and a protein disulphide isomerase-related protein expressed in urochordate gonad cytosol. Int J Biochem Cell Biol 32: 769-777.

Chan L, Wei CF, Li WH, Yang CY, Ratner P, Pownall H, Gotto AM Jr. et al. (1985) Human liver fatty acid binding protein cDNA and amino acid sequence. Functional and evolutionary implications. J Biol Chem 260: 2629-2632.

Chmurzyńska A (2006) The multigene family of fatty acidbinding proteins (FABPs): function, structure and polymorphism. J Appl Genet 47: 39-48.

Cohn SM, Simon TC, Roth KA, Birkenmeier EH, Gordon JI (1992) Use of transgenic mice to map cis-acting elements in the intestinal fatty acid binding protein gene (Fabpi) that control its cell lineage-specific and regional patterns of expression along the duodenal-colonic and crypt-villus axes of the gut epithelium. J Cell Biol 119: 27-44.

Conklin EG (1932) The embryology of amphioxus. J Morphol 54: 69-151.

Esteves A, Ehrlich R (2006) Invertebrate intracellular fatty acid binding proteins. Comp Biochem Physiol C Toxicol Pharmacol 142: 262-274.

Felsenstein J (1993) PHYLIP (Phylogeny Inference Package). Department of Genetics, University of Washington, Seattle

Fu Y, Luo N, Lopes-Virella MF (2000) Oxidized LDL induces the expression of ALBP/aP2 mRNA and protein in human THP-1 macrophages. J Lipid Res 41: 20172023.

Gordon JI, Elshourbagy N, Lowe JB, Liao WS, Alpers DH, Taylor JM (1985) Tissue specific expression and developmental regulation of two genes coding for rat fatty acid binding proteins. J Biol Chem 260: 1995-1998.

Green RP, Cohn SM, Sacchettini JC, Jackson KE, Gordon JI (1992) The mouse intestinal fatty acid binding protein gene: nucleotide sequence, pattern of developmental and regional expression, and proposed structure of its protein product. DNA Cell Biol 11: 31-41.

Haunerland NH, Chisholm JM (1990) Fatty acid binding protein in flight muscle of the locust, Schistocerca gregaria. Biochim Biophys Acta 1047: 233-238.

Haunerland NH, Spener F (2004) Fatty acid-binding proteins - insights from genetic manipulations. Prog Lipid Res 43: 328-349.

Holland LZ, Holland ND (1999) Chordate origins of the vertebrate central nervous system. Curr Opin Neurobiol 9: 596-602.

Holland LZ, Holland PWH, Holland ND (1996) In Molecular Zoology: Advances, Strategies, and Protocols. Ferraris JD, ed, pp 267-282. Wiley-Liss, New York.

Holland LZ, Laudet V, Schubert M (2004) The chordate amphioxus: an emerging model organism for developmental biology. Cell Mol Life Sci 61: 2290-2308. 
Liang Y, Zhang S (2006a) Demonstration of plasminogenlike protein in amphioxus with implications for the origin of vertebrate liver. Acta Zoologica 87: 141-145.

Liang Y, Zhang S, Lun L, Han L (2006b) Presence and localization of antithrombin and its regulation after acute lipopolysaccharide exposure in amphioxus, with implications for the origin of vertebrate liver. Cell Tissue Res 323: $537-541$.

Liu Z, Zhang S, Yuan J, Sawant MS, Wei J, Xu A (2002) Molecular cloning and phylogenetic analysis of AmphiUbf80, a new member of ubiquitin family from the amphioxus Branchiostoma belcheri tsingtauense. Curr Sci 83: $50-53$.

Maatman RG, van de Westerlo EM, van Kuppevelt TH, Veerkamp JH (1992) Molecular identification of the liver- and the heart-type fatty acid-binding proteins in human and rat kidney. Use of the reverse transcriptase polymerase chain reaction. Biochem J 288: 285-290.

Müller J (1844) Ueber den Bau und die Lebenserscheinungen des Branchiostoma lubricum Costa, Amphioxus lanceolatus. Yarrell Abh K Preuss Akad Wiss Berl 1844: 79-116.

Ockner RK, Manning JA, Poppenhausen RB, Ho WK (1972) A binding protein for fatty acids in cytosol of intestinal mucosa, liver, myocardium, and other tissues. Science 177: 56-58.

Owada Y, Yoshimoto T, Kondo H (1996) Spatio-temporally differential expression of genes for three members of fatty acid binding proteins in developing and mature rat brains. J Chem Neuroanat 12: 113-122.

Owada Y, Suzuki I, Noda T, Kondo H (2002) Analysis on the phenotype of E-FABP-gene knockout mice. Mol Cell Biochem 239: 83-86.

Pierce M, Wang Y, Denovan-Wright EM, Wright JM (2000) Nucleotide sequence of a cDNA clone coding for an intestinal-type fatty acid binding protein and its tissuespecific expression in zebrafish (Danio rerio). Biochim Biophys Acta 1490: 175-183.

Rehm BH (2001) Bioinformatic tools for DNA/protein sequence analysis, functional assignment of genes and protein classification. Appl Microbiol Biotechnol 57: 579592.

Ruppert EE (1997) Hemichordata, chaetognatha, and the invertebrate chordates. In: Microscopic Anatomy of Invertebrates. Harrison FW, Ruppert EE, eds, vol 15, pp 349-504. Wiley-Liss, New York.

Schaap FG, van der Vusse GJ, Glatz JF (2002) Evolution of the family of intracellular lipid binding proteins in vertebrates. Mol Cell Biochem 239: 69-77.
Schroeder F, Jefferson JR, Powell D, Incerpi S, Woodford JK, Colles SM, Myers-Payne S, Emge T, Hubbell T, Moncecchi D et al. (1993) Expression of rat L-FABP in mouse fibroblasts: role in fat absorption. Mol Cell Biochem 123: 73-83.

Sharma MK, Denovan-Wright EM, Degrave A, Thisse C, Thisse B, Wright JM (2004) Sequence, linkage mapping and early developmental expression of the intestinal-type fatty acid-binding protein gene ( $f a b p 2)$ from zebrafish (Danio rerio). Comp Biochem Physiol B Biochem Mol Biol 138: 391-398.

Shi YB, Hayes WP (1994) Thyroid hormone-dependent regulation of the intestinal fatty acid-binding protein gene during amphibian metamorphosis. Dev Biol 161: 48-58.

Stelmanska E, Korczynska J, Swierczynski J (2004) Tissuespecific effect of refeeding after short- and long-term caloric restriction on malic enzyme gene expression in rat tissues. Acta Biochim Polon 51: 805-814.

Surmacz L, Wiejak J, Wyroba E (2006) Cloning of two genes encoding Rab7 in Paramecium. Acta Biochim Polon 53: 149-156.

Veerkamp JH, Maatman RG (1995) Cytoplasmic fatty acidbinding proteins: their structure and genes. Prog Lipid Res 34: 17-52.

Veerkamp JH, Zimmerman AW (2001) Fatty acid-binding proteins of nervous tissue. J Mol Neurosci 16: 133-142, discussion 151-157.

Wada H, Satoh N (1994) Details of the evolutionary history from invertebrates to vertebrates, as deduced from the sequences of $18 \mathrm{~S}$ rDNA. Proc Natl Acad Sci USA 91: 1801-1804.

Welsch U (1975) The fine structure of the pharynx, cyrtopodocytes and digestive caecum of Amphioxus (Branchiostoma lanceolatum). Symp Zool So Lond 36: 17-41.

Yu LR, Zeng R, Shao XX, Wang N, Xu YH, Xia QC (2000) Identification of differentially expressed proteins between human hepatoma and normal liver cell lines by two-dimensional electrophoresis and liquid chromatography-ion trap mass spectrometry. Electrophoresis 21: 3058-3068.

Zanotti G (1999) Muscle fatty acid-binding protein. Biochim Biophys Acta 1441: 94-105.

Zhang F, Lücke C, Baier LJ, Sacchettini JC, Hamilton JA (1997) Solution structure of human intestinal fatty acid binding protein: implications for ligand entry and exit. J Biomol NMR 9: 213-228. 